\title{
The Planning for the Auditing Process in the Jordanian Commercial Banks from Perspective of the External Auditors
}

\author{
Atef Aqeel Al-Bawab ${ }^{1}$ \\ ${ }^{1}$ Irbid National University, Irbid, Jordan \\ Correspondence: Atef Aqeel Al-Bawab, Irbid National University, Irbid, Jordan. Tel: 962-777-326-901. E-mail: \\ atefbawab@yahoo.com
}

Received: April 22, 2019

Accepted: May 23, 2019

Online Published: May 28, 2019

doi:10.5539/ijef.v11n7p40

URL: https://doi.org/10.5539/ijef.v11n7p40

\begin{abstract}
The study aimed to identify on the planning for the auditing process in the Jordanian Commercial Banks from perspective the external auditors. The researcher followed the descriptive and analytical approach to collect the data, and the researcher used the questionnaire to know the opinions of the external auditors about the idea of the study. The descriptive measures, such as the arithmetic mean, also the (T-test) were used to test the hypothesis of the study. The most important results of the study was there is planning for the audit process in the Jordanian commercial banks and the external auditor examines all aspects of the Bank's activities and banking products which provide to the clients. As recommended by the study by the need to develop an audit plan that is consistent with audit standards and audit profession in the commercial banks of Jordan and The need to expand the work of questionnaires that examine the internal control systems in the banks.
\end{abstract}

Keywords: external auditor, commercial bank, planning, auditing, Jordan

\section{Introduction}

Increased attention to audit services with grows the investment and expansion of companies. At the beginning of the 20th century, demand for audit services increased to reduce the gap between owners and managers. With the emergence of so-called institutional failure, it was necessary to establish rules and scientific foundations for the process of planning the audit to reassure the owners of the project.

The study was conducted to examine the extent to which the Jordanian Public Accountant is committed to the process of planning the audit of commercial banks to avoid institutional failure.

\subsection{Study Problem}

The occurrence of any financial problem in commercial banks is working to lose confidence in the banking sector, which negatively affects on the financial policy because the commercial banks in all countries of the world are important sectors, and it is the artery of the economy, which works to provide liquidity for the financial and economic operations inside and outside of the country, The study examines the external auditor's commitment to the process of planning the audit process through the following question:

Does the Jordanian auditor prepare the audit process in the Jordanian commercial banks?

\subsection{Study Importance}

Commercial banks are important sectors in the economies of countries. Without banks, economic activity cannot carry out investment operations and facilitate business operations, and the public sector depends on them in the financial operations to regulate the business of the country.

This study is intended to show the importance of planning for auditing in this important economic sector, and to stress on the external auditor to provide adequate professional care.

Therefore, the auditor has to take the first basic step when checking, which is planning to ensure access to valid data that the auditor depends on it to prepare of his report about the financial statements of the Bank.

\subsection{Study Objective}

The main objective of the study is to identify the extent to which the auditors have been sufficiently professional care to begin planning in the audit process at the commercial banks. Also, to identify on the importance of banks 
in the economic sectors in the countries. In order to preserve the assets of banks through the study of the control systems by the external auditor, and issue the auditor's report to shareholders and related parties to make the rational decisions.

\subsection{Study Hypothesis}

H0: There is no planning for the audit process in the Jordanian commercial banks.

\section{Literature Review}

Al-Maabreh study, 2017, entitled "The Extent of obligation the public accountants Jordanian for the requirements of the planning process with the international auditing standards". The study examined the extent to which the Jordanian accountant complied with the requirements of the audit planning process according to international auditing standards. The questionnaire was used as a tool to study the data collection. The data were analyzed and the study reached several results. It is useful for the auditor to perform the necessary analyzes of the client activity to avoid making mistakes when planning the audit process.

Al-Bawab study, 2017, entitled The Extent to Which Jordanian External Auditor Comply with The Planning Process for Auditing The Private Jordanian Universities. The basic objective from this study was identifying on the planning process of audit in the universities sectors in Jordan. The study found

Many results such as: the external auditor of Jordan shall carry out an audit plan when auditing the private Jordanian universities and the audit plan helps to create a survey list at the university to reach an understanding of the internal control risk. the study has recommended that the work plan must be documented in the client file that the auditor has in his office, and the need to make comparisons on the financial statements to estimate the deviations and mentioned in the audit plan and document this in the current work file.

Bani-Ahmed and Al-Sharairi study, 2014, entitled The Relationship between Planning of Audit Process and Total Quality Management. The objective of the study was to know the effect of the planning to the audit process on the Total Quality Management (TQM). The study depends on the questionnaire model as a tool for study and data collection. A number of questionnaires were distributed to the external auditors. The study also depends on the descriptive and analytical methodology in data collection test Assumptions and access to the results. One of the most important results: There is a relationship between the variables of the audit strategy with the effectiveness of TQM and have had a significant impact. The study recommended that the External Auditor should be stressed following the important steps in the audit planning process, which will improve the effectiveness of TQM.

\section{What distinguishes the current study?}

Previous studies have been subjected to the planning process of auditing in general and some studies to specific sectors such as private universities (Al-Bawab, 2017), as well as the relationship between the planning process in auditing and TQM (Bani Ahmed and Sharairi, 2014). The current study dealt with planning the process of auditing the commercial banks in Jordan, because the sector is an important element in the financial and monetary policy in the country and must be taken care of.

\section{Theoretical Framework}

\subsection{Nature of Auditing}

Auditing is the accumulation and evaluation of evidence about information to determine and report on the degree of correspondence between the information and established criteria. Auditing should be done by a competent, independent person (Arens et al., 2014, p. 24).

\subsection{The Concept of Planning}

Planning is the development of a general strategy and detailed treatment of the nature of the work expected to be completed, and the timing required for its termination (Hijazi, 2010, p. 73).

\subsection{The Concept of Audit}

It is an organized way to objectively obtain on evidence and proof of what is recorded in the records about the economic events of the project and evaluate them to ascertain the degree of similarity between what is established and what actually exists (Dnabat, 2015).

\subsection{The Concept of Audit Planning}

According (IAS 300). It is a planning for the audit process includes a comprehensive strategy to the development of the audit plan (IFAC, 2013, 255) . 


\subsection{The Importance of Planning the Audit Process}

The importance of planning for the audit process is demonstrated by the adoption of many parts on the reports auditors, such as the management of the company, the owners, the government, the investors, and others. (Al-Matarneh, 2011, p. 16).

\subsection{Reasons for Conducting the Audit Planning Process}

There are three main reasons for the auditor to undertake the audit planning process: (Arens, Elder, Beasley, 2014, p. 228).

1). To enable the auditor to obtain sufficient appropriate evidence for the circumstances.

2). Keeping costs liability and maintain a good reputation in the business community.

3). Avoiding misunderstandings with the client is necessary for good client relations and for facilitating high-quality work at reasonable cost.

\subsection{Planning an Audit and Designing an Audit Approach}

The planning process is carried out through the following steps: (Arenas, Elder, Beasley, 2014, p. 228).

1) Accept client and perform initial audit planning.

2) Understand the client's business and industry.

3) Assess client business risk.

4) Perform preliminary analytical procedures.

5) Set materiality and assess acceptable audit risk and inherent risk.

6) Understand internal control and assess control risk.

7) Gather information to assess fraud risks.

8) Develop overall audit strategy and audit program.

\section{Statistical Analysis and Hypothesis Test of Study}

\subsection{Methodology and Population of the Study}

The study followed the descriptive and analytical approach to collect and analysis data from the population of the study. The study selected a random sample. 120 questionnaires were distributed and 115 questionnaires were retrieved or $96 \%$, which is acceptable and valid for analysis.

\subsection{The Study Tool}

A questionnaire was prepared about the literature and previous studies, I built (12) Questionnaires to measure the opinion of the sample, which were distributed on the employees in the Jordanian commercial banks. As for the study tool, the internal reliability was calculated for the study tool's axes as well as the overall reliability by using Chronbach's Alpha reliability coefficient by means of (Test and Retest). The reliability coefficient of the tool was (0.915) which is an acceptable rate in this type of studies. Look at Table 1.

Table 1. The value of Cronbach's alpha coefficient for each paragraphs of questionnaire

\begin{tabular}{ccc}
\hline The description & No. of paragraphs & Cronbach's alpha coefficient \\
\hline H0: There is not planning for the audit process in the commercial banks in Jordan. & 12 & 0.915 \\
\hline
\end{tabular}

The Table 1 showed that, the coefficient was 0.915 and this result is very high and raise on 0.60 . This is indicating to the strong and valid the collected data.

\subsection{Analysis of Collected Data}

The researcher used the Likert scale in the analysis of the views of respondents so that the distribution of scores on the answers and divided the marks to three ranks as follow (Sekaran, Uma, \& Bougie, 2010):

1) From $1-2.33$ is low. (L).

2) From $2.33-3.66$ is average. (A).

3) From 3.66- 5 are high. (H). 


\subsection{The Means and Standard Deviations for the Sample}

Computed the mean and the standard division of the paragraphs of the questionnaire as in the Table 2:

Table 2. The mean and standard deviation for the sample

\begin{tabular}{|c|c|c|c|c|}
\hline No. & Paragraph & Mean & Standard Deviation & Result \\
\hline 1 & $\begin{array}{l}\text { The external auditor examines all aspects of the Bank's activities and banking products } \\
\text { which provide to the clients. }\end{array}$ & 4.33 & .498 & $\mathrm{H}$ \\
\hline 2 & $\begin{array}{l}\text { The auditor examines internal control systems and internal Settings procedures at the } \\
\text { Bank which act to reduce risks. }\end{array}$ & 4.12 & .788 & $\mathrm{H}$ \\
\hline 3 & $\begin{array}{l}\text { The external auditor performs procedures that help him to obtain sufficient information } \\
\text { to understand the client's activity. }\end{array}$ & 3.98 & .566 & $\mathrm{H}$ \\
\hline 4 & $\begin{array}{l}\text { The external auditor examines samples of the financial transactions with the Bank's } \\
\text { departments to determine the degree of disclosure in the financial statements. }\end{array}$ & 3.91 & .711 & $\mathrm{H}$ \\
\hline 5 & $\begin{array}{l}\text { The external auditor conducts regular visits to the bank, and sometimes occasional } \\
\text { visits to ensure the normal functioning of the working at various times. }\end{array}$ & 3.46 & .499 & A \\
\hline 6 & $\begin{array}{l}\text { The external auditor reviews the records of the meetings for the Board of Directors and } \\
\text { keeps a copy in his office (current file). }\end{array}$ & 3.69 & .981 & $\mathrm{H}$ \\
\hline 7 & $\begin{array}{l}\text { The external auditor reviews the contracts signed with the bank. And shall be executed } \\
\text { through the legal department of the bank. }\end{array}$ & 4.01 & .652 & $\mathrm{H}$ \\
\hline 8 & $\begin{array}{l}\text { The external auditor performs the necessary financial analyzes and access to the most } \\
\text { important ratios in the banking sector, and compared it with the accepted ratios. }\end{array}$ & 4.41 & .775 & $\mathrm{H}$ \\
\hline 9 & $\begin{array}{l}\text { The external auditor is committed to the level of relative importance limits, and } \\
\text { assessment of the control risk, and inherent risks. }\end{array}$ & 3.31 & .579 & A \\
\hline 10 & $\begin{array}{l}\text { The external auditor compares the amounts shown in the budgets with the actual } \\
\text { financial performance, to assess the control risk, and to identify the causes of the } \\
\text { differences. }\end{array}$ & 4.43 & .895 & $\mathrm{H}$ \\
\hline 11 & $\begin{array}{l}\text { The external auditor makes a questionnaire with the top management of the Bank, to } \\
\text { identify the control risk and other risks in the Bank. }\end{array}$ & 4.61 & .477 & $\mathrm{H}$ \\
\hline 12 & $\begin{array}{l}\text { The external auditor makes comparisons with the results of the current and previous } \\
\text { years, such as comparison of administrative expenses or interest income. }\end{array}$ & 4.08 & .588 & $\mathrm{H}$ \\
\hline
\end{tabular}

The Table 2 showed that the value of the mean was the largest class (3) in all the paragraphs, which indicates that the external auditor of Jordan plans for the audit process in the banks.

\subsection{Test of the Study Hypothesis}

To test the hypothesis the researcher analyzed the data collected by using SPSS program and a One-Sample Ttest, and the Table 3 shows the results as the following:

Table 3. The test and results for the study hypothesis

\begin{tabular}{lccccc}
\hline Hypothesis. & Mean & St. Division & $\mathrm{T}-$ test & Confidence level & Result \\
\hline $\begin{array}{l}\text { Ho: There is no planning for the audit process in the Jordanian } \\
\text { commercial banks. }\end{array}$ & 4.028 & 0.783 & 21.632 & 0.000 & Rejected \\
\hline
\end{tabular}

The results showed as in the table 3 that the mean value was larger than the mean premise (3), where its value amounted to (4.028) and a standard deviation of (0.0.783), and since the test (T) calculated value was large and positive in terms amounted to (21.632), and the level of significance of this test less the level of confidence 0.05 , reaching 0.000 , the hypothesis of the study can therefore be rejected and acceptance of alternative which says: There is planning for the audit process in the Jordanian commercial banks.

\section{Conclusions and Recommendations}

\subsection{Conclusions}

1) There is planning for the audit process in the Jordanian commercial banks. It's indicate to the external auditor is working professional.

2) The external auditor examines all aspects of the Bank's activities and banking products which provide to the 
clients.

3) The auditor examines internal control systems and internal settings procedures at the Bank which act to reduce risks.

4) The external auditor performs the necessary financial analyzes and access to the most important ratios in the banking sector, and compared it with the accepted ratios.

5) The external auditor makes comparisons with the results of the current and previous years, such as comparison of administrative expenses or interest income.

6) The external auditor makes comparisons with the results of the current and previous years, such as comparison of administrative expenses or interest income.

7) The external auditor examines samples of the financial transactions with the Bank's departments to determine the degree of disclosure in the financial statements.

\subsection{Recommendations}

1) The need to develop an audit plan that is consistent with audit standards and audit profession in the commercial banks of Jordan.

2) The need to expand the work of questionnaires that examine the internal control systems in the banks.

3) The need for financial analysis and the necessary ratios to identify the deviations.

4) The need to inform senior management of the most important deviations in all levels in the bank.

5) The need to make comparisons of previous years for as long as possible.

6) The need to build the audit plan based on the analysis and the data collected.

7) Encourage other researchers to continue the work of research in this field.

\section{References}

Al-Bawab, A. (2017). The Extent to Which Jordanian External Auditor Comply with The Planning Process for Auditing The Private Jordanian Universities. Journal of Business Management and Economics, 5(9). https://doi.org/10.15520/jbme.2017.vol5.iss9.265.pp01-06

Al-Maabreh, M. F. A. (2017). The Extent of obligation the public accountants Jordanian for the requirements of the planning process with the international auditing standards. Master Thesis Unpublished, Irbid National University, Jordan.

Al-Matarneh, G. F. (2011). The extent to which Jordanian auditors comply with International Auditing Standard No. 300 under the electronic audit, -A field Study. Tishreen University Journal for Research and Scientific Studies, 33(2).

Arens, A. A., Elder, R. J., \& Beasley, M. S. (2014). Auditing and Assurance Services an Integrated Approach (15th ed.). Michigan State University, USA.

Bani-Ahmed, A. A., \& Al-Sharairi1, J. A. (2014). The Relationship between Planning of Audit Process and Total Quality Management. International Journal of Business and Management, 9(5). https://doi.org/10.5539/ijbm.v9n5p96

Dnabat, A. (2015). Audit in accordance with International Auditing Standards, and Local Laws, Theory and Practice (5th ed.). Jordan University Press, Jordan.

Hijazi, W. H. (2010). International Standards for Auditing. The Education Dare of University, Alexandria, Egypt.

International Federation of Accountants. (2010). Issuances of international standards for quality control, auditing, review and other related confirmations.

Sekaran, U., \& Bougie, R. (2010). Research Methods for Business: A Skill Building Approach. UK: John Wiley and Sons.

\section{Copyrights}

Copyright for this article is retained by the author(s), with first publication rights granted to the journal.

This is an open-access article distributed under the terms and conditions of the Creative Commons Attribution license (http://creativecommons.org/licenses/by/4.0/). 